\title{
REACHING FOR REENTRY: INDIANA UNIVERSITY ROBERT H. MCKINNEY SCHOOL OF LAW'S CONTRIBUtion to THE REENTRY MOVEMENT
}

\author{
LAHNY R. SILVA* \\ This essay is dedicated to The Honorable Judge Larry J. McKinney. \\ Words cannot express my eternal gratitude to you for being my teacher, \\ offering me wise counsel, and for also giving me wings.
}

\section{INTRODUCTION}

Criminal justice reform and reentry, in particular, enjoy broad bipartisan support and backing by government institutions, not-for-profit agencies, and religious organizations. It is truly a movement with all stakeholders in the criminal justice system, at federal, state, and local levels, working in some form or fashion toward promoting the successful reentry of those released from America's jails and prisons. Here in the city of Indianapolis, the reentry movement is in full swing, with prosecutors hosting second chance initiatives, private law firms committing their talent to pro bono service, funders pushing for evidence-based practices, and the judiciary committing resources to reentry problem-solving courts. Indianapolis, as a community, is dedicated to reducing recidivism and is experimenting with creative new ways of reintegrating formerly incarcerated people. The alliance of committed criminal justice agencies and nonprofit organizations is not only impressive, but also powerful. Indianapolis is carrying the movement forward and is doing things, as a city, that seemed impossible ten years ago.

The reentry movement occurring within the criminal justice system is something that I never could have imagined as a girl. Born in 1980, I grew up during the War on Drugs and developed a deep cynicism about the American form of criminal justice at a very young age. My perception of the criminal system was that of a monolithic enemy determined to imprison people of color under the banner of the War. As I grew, I witnessed, first-hand, the systematic obliteration of socio-economic opportunities for released prisoners, who were mostly poor and people of color. There appeared to be no way for released prisoners to successfully reintegrate into American life. It was difficult to secure employment, nearly impossible to secure safe and affordable housing, and Food Stamps were not an option. I watched as people around me grew desperate and then hopeless and then returned to the "hustle"-committing a crime for

* Professor of Law, Indiana University Robert H. McKinney School of Law. Judge Doris Pryor - a special thank you for bringing me into the fore and showing me a different system. Thank you to my family for the life experience and never-ending encouragement, and Thomas Lee Ridley for your friendship and loyalty over the years. A special thanks to the REACH Team and Professor Carrie Hagan for your dedication to the second chance ethos. To Professors Roisman, Wright, and Magliocca - thank you for always saying "yes" to reviewing my drafts. Derek Minor - the title is all you. And thank you, Judge Larry J. McKinney, for allowing me the honor and privilege to begin my life's purpose in your court. 
economic gain. I learned in law school, and later in practice at Legal Aid, that the weapons used during the War were exclusionary statutes and regulations buried in monotonous and seemingly innocuous statutory language littered throughout the federal and state legislative codes. They took the form of civil penalties that were triggered upon criminal conviction, affecting all areas of life including employment, housing, public benefits, and civic participation. ${ }^{1}$ Today, a conviction is not even required. Any negative interface with the criminal justice system that is publicly recorded, or any suspicion of criminal activity, often warrants exclusion from many programs and opportunities. To date, there are over 40,000 of these civil penalties on the books. ${ }^{2}$

As a law professor, my scholarship scrutinizes these civil penalties in depth. In my research, I discovered that these "collateral consequences of conviction" are not only numerous, but they can also exclude individuals for a lifetime. These rules operate outside the criminal sentencing process, allowing them to function outside the public purview in a shadow system of punishment. This web of obstacles works to hinder the reintegration efforts of formerly incarcerated people and the socioeconomic opportunities for anyone with a criminal history. With this, I have used my articles and essays to advocate for the repeal or modification of these rules. But for me, this was not enough.

Before coming to the academy, I was a staff attorney working for Greater Hartford Legal Aid in Hartford, Connecticut. Practice provided me with not only legal experience but also client contact, community involvement, and courtroom engagement. In my role as an untenured professor, I found myself limited to the classroom and scholarship. I wanted more not only for myself but for my students. I wanted them to see the law in practice. In 2015, the opportunity to do so knocked on my door in the form of then Assistant United States Attorney, now Federal Magistrate Judge, Doris L. Pryor. She approached me about the

1. See generally Gabriel J. Chin, The New Civil Death: Rethinking Punishment in the Era of Mass Conviction, 160 U. PA. L. Rev. 1789 (2012); Michelle AleXander, The New Jim Crow (2010); Pew Charitable Trs., Collateral Costs: Incarceration's EfFect on Economic MobILITy 11 (2010); Lahny R. Silva, Clean Slate: Expanding Expungements and Pardons for NonViolent Federal Offenders, 79 U. Cin. L. Rev. 155, 165 (2010); Michael Pinard \& Anthony C. Thompson, Offender Reentry and the Collateral Consequences of Criminal Convictions: An Introduction, 30 N.Y.U.REV.L. \& Soc. CHANGE 585, 594-99 (2006); JEFF MANZA \& CHRISTOPHER Uggen, Locked Out: Felon Disenfranchisement And American Democracy (2006); Christopher Mele \& Teresa A. Miller, Collateral Civil Penalties as Techniques of Social Policy, in Civil Penalties, Social Consequences 9, 19-20 (Christopher Mele \& Teresa A. Miller eds., 2005); Margaret Colgate Love, Starting Over with a Clean Slate: In Praise of a Forgotten Section of the Model Penal Code, 30 Fordham Urb. L.J. 1705, 1719 (2003); Jeremy Travis, Invisible Punishment: An Instrument of Social Exclusion, in Invisible Punishment: The Collateral Consequences of MAss Imprisonment 15, 20-22 (Marc Mauer \& Meda Chesney-Lind eds., 2002).

2. Council of State Gov'ts Justice Ctr., After the Sentence, More Consequences: A National Snapshot of Barriers to Work, at 2 (Jan. 2021), https://csgjusticecenter.org/publications/after-thesentence-more-consequences/national-snapshot/ [https://perma.cc/R24L-NWP6]. 
possibility of the law school's involvement in a pilot mentor program in the Southern District of Indiana's Re-Entry And Community Help program, or the REACH program. I jumped at the chance. Unbeknownst to any of us, this started a wave of movement, collaboration, and commitment to reentry at Indiana University Robert H. McKinney School of Law ("McKinney").

Since 2015, McKinney has allowed me the privilege to work on the issue of reentry with a more hands-on approach to address the collateral consequences of conviction. With my colleague, Professor Carrie Hagan, and the dedication of McKinney students, we created a reentry program at the law school that provides the Indianapolis community with a plethora of targeted pro bono reentry services. In doing so, we have helped thousands of people in Indianapolis with reentry related issues, including employment, housing, driver's licenses, child support, and expungement. We have partnered with dozens of community organizations across the city and even created our own law student organization to provide dedicated community service to those returning home from prison or jail. This essay will review the different reentry related initiatives here at McKinney.

There are a number of wonderful reentry programs in cities across the nation, both in the form of reentry problem-solving courts and reentry clinics. This essay hopes to add a reentry model, albeit an ever-developing work-in-progress, to the existing catalogue of successful reentry initiatives. McKinney's reentry efforts are innovative, collaborative, and effective. This essay is meant to serve as a blueprint for interested stakeholders and as an aspiration for law schools across the country.

This essay begins with an in-depth review of McKinney's involvement with the federal Re-Entry And Community Help program in the Southern District of Indiana. Perhaps most vital to the success of the REACH program is the use of evidence-based practices when interfacing with program participants. This section of the essay offers an evaluation of the ways in which REACH Team members employ these techniques. This section also provides an overview of the REACH program, describes the mentor-advocacy program design, and discusses the types of assistance that law students provide. It concludes with a consideration of whether REACH works in terms of reducing recidivism. Section II discusses the law student organization, the Second Chance Reentry Assistance Program, or "SCRAP", and their community outreach initiatives. This section focuses on the formation of SCRAP as a law student group as well as the evolution of the reentry outreach series and the hope that it brings to the hot spot areas in Indianapolis. Section III examines the annual Reentry Fair. This section emphasizes the use of partnerships and meeting people where they are. Section IV discusses the Clemency Project 2014. Though only tangentially related to direct reentry services, this section discusses the importance of reentry programming in prisons and the way in which prerelease planning is becoming significant. Finally, Section V offers a brief conclusion. 


\author{
I. $\mathrm{REACH}^{3}$ \\ "He reached down from on high and took hold of me; he drew \\ me out of deep waters." \\ -2 Samuel 22:17
}

The Re-Entry And Community Help program, or REACH, is a reentry problem-solving court in the United States District Court for the Southern District of Indiana. The purpose of the REACH program is to improve the prospects of a successful reintegration for moderate to high-risk federal prisoners returning to Indianapolis. ${ }^{4}$ This is achieved by using evidence-based practices to address criminogenic factors associated with criminal recidivism such as requiring a high level of accountability and facilitating community networks. ${ }^{5}$ With this, REACH is designed to provide prosocial support and targeted resources that address criminogenic traits and barriers to reentry. ${ }^{6}$

The REACH court began on October 4, 2007, under the judicial stewardship of The Honorable Judge Larry J. McKinney. Judge McKinney was nominated to a seat on the United States District Court for the Southern District of Indiana by President Ronald Reagan on May 5, 1987, and was confirmed by the Senate in July of 1987. ${ }^{7}$ During his tenure, he served as Chief Judge from 2001 to 2007 and later assumed senior status in 2009, where he served until his tragic and sudden passing on September 21, 2017. ${ }^{8} \mathrm{REACH}$ was one of his most cherished achievements, and he served as a REACH judge until his death.

The founding team members included Judge McKinney, Federal Magistrate Judge Tim Baker, Assistant U.S. Attorney Doris L. Pryor (now Federal Magistrate Judge Pryor), Federal Defender Jim McKinley, U.S. Probation Officer

3. See generally Marilyn Odendahl, IU McKinney Students Bring Energy, Enthusiasm to Re-Entry Program, IND. LAw. (May 14, 2019), https:/www.theindianalawyer.com/articles/50271iu-mckinney-students-bring-energy-enthusiasm-to-re-entry-program [https://perma.cc/M7WZYVV7]; Marilyn Odendahl, 'Beautiful Help' Allows Federal Ex-Offenders to Remake Lives, IND. LAw. (Sept. 19, 2017) https://www.theindianalawyer.com/articles/44840-beautiful-help-allowsfederal-ex-offenders-to-remake-lives [https://perma.cc/5N5R-38LL] [hereinafter Beautiful Help].

4. Southern District of Indiana Re-Entry And Community Help Program, Policy and Procedure 1-3 (revised Dec. 8, 2015) (on file with the author) [hereinafter REACH Policy and Procedure].

5. Id.

6. See generally id. Criminogenic traits include antisocial peers, antisocial personality (impulsivity, aggression, and pleasure seeking) and procriminal attitudes. For more information, see James Bonta \& Don Andrews, Viewing Offender Assessment and Rehabilitation Through the Lens of the Risk-Need-Responsivity Model, reprinted in OFFENDER SUPERVISION: NEW DIRECTIONS in Theory, Research And Practice 19-40 (Fergus McNeill et al. eds., 2010),

7. McKinney, Larry J., FED. JUD. CTR., https://www.fjc.gov/history/judges/mckinney-larry-j (last visited Sept. 3, 2021) [https://perma.cc/PD6A-V6LM].

8. Id. 
Michael Burress, and Judge Baker's Courtroom Deputy, Amy Holtz. ${ }^{9}$ The original team members have since changed, though the involved offices continue to participate. Today, the REACH Team consists of two REACH courts, with the Honorable Judge Tanya Walton Pratt presiding over the second court and Senior U.S. Probation Officer and Reentry specialist Ryan Sharp supervising probationers in both courts. Though Officer Burress has since advanced into a more senior supervisory position, he continues to attend REACH hearings and support the REACH court.

REACH operates in two phases. The first phase is called "intensive supervision." Intensive supervision requires that the probationer report to the REACH court on a monthly basis until he or she has acquired twelve certificates in addition to reporting, home-visits, and urinalysis. The purpose of court attendance is to ensure a high level of accountability. ${ }^{10}$ The certificates symbolize a month of compliance or success, or both. If a probationer fails to comply by testing positive for narcotics or lying to the court, for example, then he or she may not receive a certificate and must then complete an additional month to obtain the requisite certificates to graduate from Phase I. Once an individual secures twelve certificates, he or she then moves to "passive probation." Court attendance is not required during passive probation and the probationer experiences a more traditional supervision approach with only reporting, homevisits, and urinalysis. Once an individual has completed one year on passive probation, he or she is then considered eligible for early termination from supervision. Early termination means that probation is over; the probationer is "emancipated" early from the custody and control of the criminal justice system.

The REACH program is highly selective, with participants volunteering to participate. The program targets moderate to high-risk of recidivism federal probationers (as measured in accordance with the Post Conviction Risk Assessment or "PCRA") who also demonstrate a positive attitude but need more intensive support. REACH participants typically have underlying offenses that include felon in possession of firearm, drug conspiracy, or robbery. Sex offenders and particularly violent offenders are ineligible for the program due to the different and more intensive needs of this profile of offender. ${ }^{11}$

The REACH Team employs evidence-based practices and engages with program participants outside the walls of the federal courthouse. REACH participants are provided with wrap-around reentry services with the help of McKinney law students. And the numerous obstacles and barriers presented by laws and societal stigmatization are confronted as a Team with the hopes of clearing the path for the REACH participants to eventually lead a stable, independent, and productive life.

9. Tim A. Baker, Taking It Personally: How Making Connections Makes a Difference in the Success of Reentry Courts, 54 IND. L. REV. 549, 551 (2021).

10. REACH Policy and Procedure, supra note 4, at 2.

11. Baker, supra note 9 , at 552 . 


\section{A. Best Practices}

Perhaps the most critical aspect of the REACH program is that every team member employs evidence-based practices, whether intentional or not. From the probation officer to the judges to the federal prosecutors, we all use with the participants key strategies that are statistically correlated with a lower rate of recidivism. Over the past few decades, meta-analyses were conducted reviewing hundreds of studies that examine supervision practices. ${ }^{12}$ These studies show that some practices are correlated with lower rates of recidivism. ${ }^{13}$

The most successful supervision practices concentrate on medium to highrisk individuals with a specific focus on addressing criminogenic factors through behavioral interventions and social services. ${ }^{14}$ While control and punishment strategies were shown to be ineffective at reducing recidivism, the more successful programs implemented cognitive-behavioral techniques (CBTs). ${ }^{15}$ More specifically, meta analytical studies point to prosocial modeling, problem solving, and the appropriate use of authority as strongly related to a reduction in recidivism. $^{16}$

1. Prosocial Modeling.- One study found that prosocial modeling was the most closely related to a reduction in recidivism than any other supervision practice or skill. ${ }^{17}$ It involves the development of prosocial values that include value-laden principles such as fairness and reliability. ${ }^{18}$ It entails encouraging a crime-free lifestyle by using positive reinforcement to validate statements and behaviors of the probationer that reflect prosocial values. ${ }^{19}$ Thus, the use of

12. Chris Trotter, Reducing Recidivism Through Probation Supervision: What We Know and Don't Know from Four Decades of Research, 77 FED. Prob., Sept. 2013, at 43, 43-48 [hereinafter Trotter, Reducing Recidivism].

13. Id. at 47.

14. Id.; see D.A. Andrews \& Craig Dowden, Risk Principle of Case Classification in Correctional Treatment: A Meta-Analytic Investigation, 50 INT'L J. OFFENDER THERAPY \& COMP. CRIMINOLOGY 88, 88-100 (2006). As mentioned above, REACH participants are moderate to highrisk individuals.

15. Friedrich Lösel, What Works in Reducing Reoffending: A Global Perspective, Paper Presented at the 12th Annual Conference of the International Corrections and Prisons Association (Apr. 27, 2010), at 17, 20, https://www.yumpu.com/en/document/read/51114216/what-works-inreducing-reoffending-a-global-perspective [https://perma.cc/4Q6W-4YTP].

16. Trotter, Reducing Recidivism, supra note 12, at 44; see generally D.A. ANDREWS ET AL., Volunteers and the One-to-One Supervision of Adult Probationers: An Experimental Comparison With Professionals and a Field-Description of Process and Outcome (1979).

17. Trotter, Reducing Recidivism, supra note 12, at 45; see also Peter Raynor et al., The Impact of Skills in Probation Work: A Reconviction Study, 14 CRIMINOLOGY \& CRIM. Just. 235, 243 (2014) (reporting prosocial modeling significantly related to low recidivism at one-year and two-year follow up, though it was only statistically significant at one-year).

18. Trotter, Reducing Recidivism, supra note 12, at 46.

19. Id. at $45-46$. 
incentives and sanctions are employed to shape behavior. ${ }^{20}$

In $\mathrm{REACH}$, we reward prosocial behavior in two ways. First, we use the certificate as a reward. Certificates are awarded to individuals who are in compliance with their conditions of supervision and/or are making positive steps toward achieving personal goals. If an individual does not receive a certificate, we often offer the opportunity to earn it back in subsequent months. Second, we encourage prosocial conduct and behavior through very basic human acts of validation and words of encouragement. We clap when participants achieve goals, overcome obstacles, and make significant career advancements. We clap as a group: the REACH Team, the law students, and the other participants. Judge Pratt and Judge Baker offer praise upon the accomplishment of goals and encouragement when participants are facing difficult times. Finally, with regard to issues of non-compliance, the REACH Team employs a graduated sanction response. Issues of non-compliance are dealt with swiftly, and may result in withholding the certificate, filing of a violation, or revocation. The sanction depends on the number and/or gravity of issues of non-compliance. Even when faced with negative or deviant behavior, the REACH Team models prosocial values by addressing noncompliance in a fair and transparent way. If the issue of non-compliance involves a new offense, we respect our participants' Fifth Amendment privilege and allow the criminal process to dispose of the case before issuing a sanction.

2. Problem Solving.-Problem solving is also a supervision best practice and is significantly related to recidivism. ${ }^{21}$ Studies define problem solving differently, but most definitions involve identifying problems (such as family issues or drugs), goal setting to tackle problems, and developing strategies to accomplish goals. ${ }^{22} \mathrm{~A}$ critical feature of the practice is allowing the probationer to express the problem and possible solutions and being sure to work with the probationer's understanding of the problem. ${ }^{23}$ The REACH judges are very good at this. Judge

20. Faye S. Taxman, The Role of Community Supervision in Addressing Reentry from Jails, Paper Prepared for Urban Institute, John Jay College, and Montgomery County, Maryland's Department of Corrections and Rehabilitation Reentry Roundtable on Reentry from Jails (June 2006), at 4, https:/www.urban.org/sites/default/files/2015/02/19/taxman_ui_revised.pdf [https:// perma.cc/E6CE-XBKP] [hereinafter Taxman, Community Supervision].

21. Raynor et al., supra note 17, at 235-49; Christopher Trotter, The Impact of Different Supervision Practices in Community Corrections: Cause for Optimism, 29 AUSTRALIAN \& N.Z. J. CRIMINOLOGY 1, 1-19 (1996) [hereinafter Trotter, The Impact] (reporting that problem-solving was related to recidivism but only significantly related to compliance with conditions rather than reoffending).

22. Trotter, Reducing Recidivism, supra note 12 , at 47.

23. See Trotter, The Impact, supra note 21; Charles R. Robinson et al., A Random (Almost) Study of Staff Training Aimed at Reducing Re-arrest (STARR): Reducing Recidivism Through Intentional Design, 75 Fed. Prob., Sept. 2011, at 57, 57-58; see generally Christopher Trotter, Effective Supervision of Young Offenders, in What Works IN Offender Compliance: International Perspectives and Evidence-Based Practice 227 (Pamela Ugwudike \& Peter Raynor eds., 2013). 
Pratt and Judge Baker ask every participant how the month went and if they confronted any new issues. They also circle back to revisit goals and check-in on any progress or setbacks in achieving those goals. In doing this, Judge Pratt and Judge Baker give participants the lead voice in identifying their own issues and setting the goals to tackle them.

While we conduct intake and assess issues, we do look to our participants to set their own goals. Throughout Phase I, the judges continue to check in on these goals. And when the goals have been accomplished, we ask participants to set new goals. The probation officer and the law students work with participants throughout the month to develop a strategy to achieve the participants' goals. For example, if a participant identifies vocational training as a goal, the law students will work with the participant to formulate a to-do list to achieve that goal. This could include updating a resume, retrieving transcripts, writing a personal statement, etc. Many participants need a great deal of hands-on assistance tackling goals, so the law students work closely with participants to complete necessary tasks such as drafting letters or applying online. If the participant's application requires a college-related transcript earned while in prison, the probation officer will take the lead reaching out to the Bureau of Prisons. Another example is mental health treatment. Counseling and therapy are often a mutually developed goal between the REACH Team and the participant, usually when the participant has a history of substance abuse or mental health issues and is facing a particularly distressing time in his or her life. The probation officer facilitates connections with mental health and substance use services as well as with community resources that provide cognitive behavioral therapies such as Moral Reconation Therapy (MRT).

The approach employed by the REACH Team accomplishes two important objectives. First, it facilitates the change process within the participant by allowing the participant to act on his or her own interests while simultaneously attacking criminogenic drivers. ${ }^{24}$ In order to set the probationer on a productive path for himself or herself as well as for society, criminogenic needs must be addressed in conjunction with a non-criminogenic interest or value identified by the probationer. ${ }^{25}$ Thus, allowing our participants to set their own goals empowers them to take ownership of positive and prosocial choices. ${ }^{26}$ Second, deportment occurs. Deportment is "the process of developing a trusting relationship" with the state. ${ }^{27}$ It occurs where the probationer believes that the state is acting fairly. ${ }^{28}$ By working closely with our participants, providing one-on-one assistance, and connecting them to community supports, we demonstrate our commitment to their success. And, perhaps more importantly, that the state, the same system that imprisoned them, is also invested in their success.

3. Appropriate Use of Authority.-The appropriate use of authority is key to

24. Taxman, Community Supervision, supra note 20, at 18.

25. Id. at $19-20$.

26. Id.

27. Id. at 6 .

28. Id. 
the successful reintegration of individuals. The relationship between officer and probationer is extremely important. ${ }^{29}$ Compliance is the outcome of how individuals sense they are being treated by the "system" and whether the "system" is treating them like others. ${ }^{30}$ With this, principles of procedural justice demand that probationers are treated as citizens during the supervision process in order to facilitate a sense of ownership and accountability within the probationer. ${ }^{31}$ When the probationer believes that his or her own behavior does not matter because the "system" is unfair and unfairly applies the rules, the probationer feels that he or she exists outside the bounds of legitimate society. ${ }^{32}$ In many instances, an "outlaw" persona is adopted because the individual is not given the chance to be a citizen. ${ }^{33}$

The research demonstrates that some officer behaviors are associated with higher recidivism rates. For example, higher recidivism was linked to the frequency of discussing conditions of supervision. "A preoccupation with the conditions of probation, or the enforcement role of the probation officer," hinders the development of a cooperative rapport, "thereby creating an obstacle to more directive intervention." 35 One study reported that the perception of a trusting relationship with the probation officer affected the likelihood of arrest for a new offense. ${ }^{36}$ Research shows that even in the case of negative outcomes, the way the authority figure addresses the situation influences the individual's level of acceptance of the situation and the sanctions. ${ }^{37}$ By simply acknowledging system inadequacies, officers may foster a sense of fairness within an individual. ${ }^{38}$ Officers should assume that the individual is reacting to the "system" as opposed to being defiant. ${ }^{39}$

The probation officer involved in the REACH program is a reentry specialist schooled in the literature of evidence-based practices. The current officer, Senior Officer Ryan Sharp, treats participants in the program with dignity and respect. $\mathrm{He}$ is fair and well-balanced in his approach to supervision, always sure to use

29. See James Bonta et al., An Experimental Demonstration of Training Probation Officers in Evidenced-Based Community Supervision, 38 CRIM. Just. \& BeHAv. 1127, 1145 (2011); see generally D.A. Andrews \& James Bonta, Rehabilitating Criminal Justice Policy and Practice, 16 Psychol., PuB. POL'Y, \& L. 39 (2010).

30. Taxman, Community Supervision, supra note 20, at 22.

31. Id.

32. Id.; see Faye Taxman et al., Racial Disparity and the Legitimacy of the Criminal Justice System: Exploring Consequences for Deterrence, 16 J. HEALTH CARE FOR POOR \& UNDERSERVED 57 (2005) [hereinafter Taxman et al., Racial Disparity].

33. See Taxman, Community Supervision, supra note 20, at 22; Taxman et al., Racial Disparity, supra note 32.

34. Bonta et al., supra note 29 , at 1145-46.

35. Id. at 1146; see also D.A. Andrews \& James Bonta, supra note 29.

36. Trotter, Reducing Recidivism, supra note 12, at 47.

37. Taxman, Community Supervision, supra note 20, at 23.

38. Id.

39. Id. 
evidence-based practices. For example, the acquisition of a valid driver's license is regularly a participant goal. However, many participants are often tempted to drive, as public transportation is often unreliable and does not provide transit around the clock. Any violation of local, state, or federal law is also a violation of supervision. Thus, instead of constantly reminding participants that a violation of traffic laws is a violation of supervision, he uses participant goals as his primary tool. Officer Sharp communicates that a traffic violation would severely hinder the goal of securing a valid driver's license and would also be a huge setback.

With issues of non-compliance, Officer Sharp is swift and reasonable. Officer Sharp immediately addresses incidents of non-compliance by first communicating to the participant that a sanction will be imposed and then implementing the sanction within the month (barring any special circumstances). He also uses reasonable sanctions to correct behavior and encourage prosocial thinking. To address substance use or to prevent further development of criminogenic behaviors, Officer Sharp looks to more treatment-based programming supported by data such as MRT. Nevertheless, because he is fair and respectful to the participants, participants accept sanctions received as a fair response from the system. The REACH Team, as a whole, mimics the approach taken by probation, but this is especially true of the judges.

Judge Pratt and Judge Baker set the tone of the REACH program. The significance of this tone cannot be overstated. They are not only the highest authority in the courtroom, but they also stand as the example of what us mere mortals can only aspire to be. Most importantly, the REACH judges treat the participants with dignity and respect. When monthly certificates are handed out, Judge Pratt and Judge Baker get off the bench, hand the certificate to the participant, and shake his or her hand (post-COVID, it is a fist bump). That action says so much to the participant, most notably that the most powerful person in the courtroom sees him or her as a person rather than a criminal. The judges work with participants throughout Phase I to not only hold higher risk individuals accountable, but to also show participants that the system will and does see them as legitimate members of society. In presiding over the REACH hearings, Judge Pratt and Judge Baker establish the authenticity of the program through their genuine expressed interest in the lives of the participants and even-handed approach in dealing with their individual frailties. This in turn creates a sense of legitimacy about the program as well as a feeling of being supported for the participants. The synergy this creates results in a cooperative and collaborate relationship between the REACH program and the participants. The outcome: lower recidivism.

\section{B. "Beautiful Help" 40}

The law school mentor program officially started in 2015 as a pilot program in collaboration with the United States Attorney's Office for the Southern District 
of Indiana, the Indiana Federal Community Defenders, and the United States Probation Department. The purpose of the mentor program was twofold. First, the program aimed at helping formerly incarcerated individuals successfully reenter society. Second, it would allow law students to receive firsthand experience regarding the implications of a criminal conviction and give lawyers in the field an opportunity to give back through pro bono service.

The program started with two federal probationers participating in REACH being paired with two McKinney law students supervised by a faculty member (me). Today, the mentor program has twelve law students participating in two REACH courts, mentoring between ten and fourteen federal probationers. Participating law students receive four Advanced Course Related Experience (ACRE) credit hours for a two-semester commitment. Mentors and mentees are permitted to communicate via a shared email or a Google Voice telephone number. Physical meetings are only permitted at McKinney and under the supervision of the faculty member. With the pandemic, we transitioned to a Zoom format for the most part, making allowances for telephone conferences for those that have difficulty with or do not have Internet service.

The role of the law student is to offer guidance in problem solving, serve as an advocate, and be a conduit to legal representation. The goal is that the barriers to reentry will be disentangled with the guidance and advocacy of the law student. In a situation where the law student finds that a given issue will require representation (e.g., eviction, Social Security, reinstatement of licenses, etc.), the law student will find a participating attorney specializing in that specific area to either represent or provide supervision to the law student on a pro bono basis so that the law student may provide legal representation to the mentee. Law students are permitted to work on the legal issue with the lawyer, attend all legal and administrative proceedings, and if properly supervised, may represent the mentee at legal and administrative proceedings. The extent of student involvement in any legal proceeding is within the discretion of the licensed attorney and the supervising faculty member.

\section{Bulldozing Barriers}

The goal of REACH is to prevent recidivism and successfully reintegrate newly released persons back into the Indianapolis community. In our quest to achieve these goals, it is crucial that this population be afforded the opportunity to acquire the basics necessary to live a decent existence after they have paid their debt. Law students follow a protocol that requires to first triage and then stabilize. They attack employment, housing, driver's licenses, food security, and health insurance issues first. If, and only if, those areas are stabilized, law students then move on to longer term goals such as businesses and not-for-profit organizations.

Employment cuts recidivism in half. ${ }^{41}$ Of the over 40,000 collateral

41. See generally Pew Charitable Trs., supra note 1, at 22-23; JANine Zweig et AL., ReCidivism EFFECTS OF THE CENTER FOR EMPLOYMENT OpPortunities (CEO) PROGRAM VARY BY Former Prisoners' RISK OF REOFFENDING 11-12 (2010), https://www.mdrc.org/ 
consequences mentioned above, approximately sixty-five percent are employment related. ${ }^{42}$ The mentor program attacks employment in two ways. First, we draft a resume. Law students draft a resume from information culled from the participant and the Bureau of Prisons Progress Report. With resume in hand, law students help participants post their resumes online and apply for specific jobs. The objective is for the participant to leave the program with long-term and meaningful employment. Second, we attempt immediate job placement. From our work over the past few years, our program has developed relationships with transitional employers such as Goodwill Industries and RecycleForce that will hire REACH program participants immediately upon release. In addition, we utilize staffing agencies to fill in employment gaps. The employment strategy continues after the participant is employed, as the search for a better paying and more desirable job is unremitting.

Housing is the one of the most significant impediments facing the reentering population today. ${ }^{43}$ Nevertheless, law students are proving to be quite successful in placing the participants in safe and affordable housing. We have worked closely with Partners-in-Housing, an organization that provides housing to lowincome Hoosiers with a criminal history. ${ }^{44}$ Additionally, law students have created an internal housing list that is prescreened for criminal history policies and look-back periods. Many of the participants have never had their own apartment and are unfamiliar with the process of acquiring housing. Law students help create a budget and set financial goals to ensure affordability and success in retaining the apartment. In addition, law students provide critical support in filling out the application and understanding the lease (tenant obligations in particular). In cases where the participant is without any furnishings, law students have found creative ways to offer support in-kind. For example, law students have discovered organizations that offer furniture on a sliding scale or free of charge. We have also received quality donations from law students and lawyers in the community.

Law students also assist REACH participants with driver's license issues and work-related documentation. Law students sort out license issues and research the necessary processes to resolve the issue. Whether the issue is hardship licenses, license reinstatement, or acquiring a license for the first time, law students provide invaluable guidance and support. The importance of a license and workrelated documentation cannot be overstated. Law students immediately go to

sites/default/files/full_490.pdf [https://perma.cc/3MNT-4PJ3]; MiLES D. HARER, RECIDIVISM AMONG FEDERAL PRISONERS RELEASED IN 1987, at 4-5 (1994), https://www.bop.gov/resources/ research_projects/published_reports/recidivism/oreprecid87.pdf [https://perma.cc/2EJC-QVDL]; Christopher Uggen, Work as a Turning Point in the Life Course of Criminals: A Duration Model of Age, Employment, and Recidivism, 67 Am. Soc. REV. 529 (2000).

42. Council of State Gov'ts Justice Ctr., supra note 2, at 2.

43. Coffey Consulting, LlCet al., Evaluation of the Prisoner Re-Entry Initiative: FINAL REPORT 107 tbl.IV.19 (2009).

44. PARTNERS IN HousInG, https://www.partnersinhousingindy.org/housing (last visited Sept. 3, 2021) [https://perma.cc/A7XB-QUSC]. 
work by providing assistance in acquiring licenses, social security cards, and birth certificates.

Food insecurity is an issue we often face in the REACH program. Already strapped for cash, many mentees have difficulty acquiring healthy food from supermarkets. Indianapolis has many "food deserts," and those deserts are typically located in areas where our REACH mentees live. ${ }^{45}$ To combat this, law students have a two-pronged strategy. Currently, we are working with Light of the World Christian Church, which has agreed to provide five to seven baskets of food twice per month to the program. These are reserved for the most food insecure participants in the program. Second, law students assist the participant with a food stamp or SNAP application and the accompanying processes.

Finally, the last triage item is the acquisition of health services and insurance. When individuals are released from prison, there is frequently a gap in medical treatment (e.g., medications and therapies), often resulting in a disruption of critical medical care. For example, abruptly stopping a prescription medication regiment may lead to serious health and/or psychological effects that can negatively impact an individual's transition. With this in mind, law students assist with subsidized health care applications and help participants navigate the processes to acquire health insurance. They also provide guidance and support in acquiring appropriate health services, including mental health and substance abuse treatment. We research and provide meeting lists for Narcotics Anonymous, Heroin Anonymous, and Crystal Meth Anonymous to participants and information regarding mental health service providers. Law students also assist participants in obtaining eyeglasses, free dental services, and finding a primary care physician.

With the more stable participants, law students have worked to provide resources to assist individuals wishing to start small businesses and non-profits. Law students research, help brainstorm and strategize ideas, and connect participants with law firms with a more sophisticated understanding of business law. Attorneys are recruited from within the ranks of the Indianapolis legal and business communities as well as McKinney alumni.

\section{Does It Work?}

The United States Sentencing Commission understands recidivism as referring "to a person's relapse into criminal behavior, often after the person receives sanctions or undergoes intervention for a previous crime." ${ }^{.46}$ The

45. See Taylor Haggerty, Food Insecurity in Indiana Reaches 14.4 Percent, IND. Pub. MEdiA (May 12, 2017), https:/www.indianapublicmedia.org/news/food-insecurity-indiana-reaches-144percent-1 19808.php [https://perma.cc/QSY3-B9HV]; Year in Review: Work to End Food Deserts Continues, INDIANAPOLIS RECORDER (Dec. 24, 2019), http:/www.indianapolisrecorder.com/health/ article_330b5d5c-265a-11ea-b7b1-c3a898fe52b8.html [https://perma.cc/XFF8-3LVM].

46. Kim Steven Hunt \& Robert Dumville, Recidivism Among Federal Offenders: A Comprehensive Overview, U.S. SENT'G COMMISSION 7 (Mar. 2016), https:/www.ussc.gov/sites/ default/files/pdf/research-and-publications/research-publications/2016/recidivism_overview.pdf 
Commission measures recidivism "by criminal acts that resulted in the rearrest, reconviction, and/or reincarceration of the offender over a specified period of time." ${ }^{47}$ In the federal system, however, recidivism is defined as "as any arrest or technical violation while on supervision resulting in revocation" of supervised release. ${ }^{48}$ In a 2019 report, the United States Sentencing Commission made an important acknowledgement. ${ }^{49}$ It declared that it could not "state with certainty how often revocations are based on new crimes versus technical violations because the underlying basis for the revocation could not be determined in 38.7 percent of the cases studied." ${ }^{50}$ This is important as it provides an explanation and perhaps, justification, for measuring the recidivism rate solely by revocation.

The recidivism rate for federal and state prisoners is higher than that of REACH participants. In a 2016 study, the United States Sentencing Commission reported on a cohort of prisoners released in 2005 and discovered that 76.6 percent of those released from state prison were rearrested within five years, while the recidivism rate for those released from federal prison was 44.9 percent. ${ }^{51}$ In terms of those placed on probation, supervised release, or community corrections, the Bureau of Justice Statistics reported that of the federal prisoners conditionally released from federal prison in 2005, 47 percent were arrested within five years, while 77 percent of state prisoners released were arrested. $^{52}$ The current recidivism rate of the REACH program, as measured by reincarceration through revocation, is 36 percent, though it is important to note the REACH sample size is very small, including only seventy-five participants. ${ }^{53}$ Thus, the REACH recidivism rate is 8 percent lower than the national average for federal prisoners and 40 percent lower than that for state prisoners.

Another question is whether the addition of the law school mentor-advocacy program had any effect on the recidivism rate. Officer Sharp's report suggests that it did. Prior to the law school joining REACH, the recidivism rate of REACH participants was about 45 percent. ${ }^{54}$ The recidivism rate did not change when the law school first joined in 2015. However, in 2016, the recidivism rate decreased significantly to 38 percent: a seven-point reduction. In 2017, the recidivism rate

[https://perma.cc/W34R-GWFB] (citation omitted).

47. Id.

48. Ryan Sharp, REACH Recidivism Report 1 (Oct. 2020) (unpublished report) (on file with author).

49. Tracey Kyckelhahn \& S. Alexander Maisel, U.S. Sentencing Comm’n, Revocations Among Federal Offenders 2-3 (2019).

50. Id. at 2. The study did report a range in comparing the two providing that "between 38.9 percent and 77.5 percent of the revocations studied were for new crimes, and between 22.5 and 61.1 percent were for technical violations." Id. at 2-3.

51. Hunt \& Dumville, supra note 46, at 15; see also Matthew R. Durose et al., Recidivism of Prisoners Released in 30 States in 2005: Patterns from 2005 to 2010, BuREAU Just. STAT. 1 (Apr. 2014), http://www.bjs.gov/content/pub/pdf/rprts05p0510.pdf [https://perma.cc/H2R8-U5ZB].

52. Id.

53. Sharp, supra note 48, at 1; see also Baker, supra note 9 , at 554-55.

54. Sharp, supra note 48 , at 5. 
continued to drop to 36 percent. Over the past three years, the recidivism rate has stayed constant at 36 percent, but projections for this year show yet another possible reduction; if all active participants do not re-offend, we may see a recidivism rate as low as 19 percent. ${ }^{55}$

The REACH program offers moderate and high-risk participants access to quality wraparound services and the encouragement of a dedicated team that employs evidence-based practices to provide support through the reentry process. The internal REACH recidivism reports demonstrate that the program is working. ${ }^{56} \mathrm{REACH}$ not only operates as a safety-net for those returning home, but also prevents criminal behavior, which in turn protects public safety. REACH, however, does something else as well. It inspires a positive perception of the criminal justice system by those most inclined to possess a negative attitude: criminal defendants. Because the REACH team delivers on its promises of support, access to resources, and graduated sanctions, REACH participants often exit the justice system with a more optimistic view of it. Many leave believing the system can be fair, reliable, and transparent. That in itself is a feat.

\section{REENTRY OUTREACH}

\section{"I am not an optimist, but a great believer of hope." -Nelson Mandela}

The Second Chance Reentry Assistance Program ("SCRAP") is a direct outgrowth of the REACH mentor advocacy program. Law students participating in the REACH program witnessed the lack of resources, support, and opportunities for those returning home from federal prison and were moved to do something about it. In the spring of 2016, seven REACH students officially formed a law student group and called it SCRAP. From there, SCRAP began its work.

The mission of SCRAP is to assist formerly incarcerated people and support organizations that provide services and resources to those with criminal histories. Understanding that community support and contact with outside agencies is related to lower rates of recidivism, ${ }^{57}$ SCRAP sought to explore reentry resources in the city. For the past few years, SCRAP has demonstrated that it is a reliable community support that is welcoming, non-judgmental, and delivers. SCRAP not only provides direct services, but also connects outreach participants to additional community resources to help address their specific issues.

Known as the "Hope Hustlers," students involved in SCRAP bring hope to often depressed areas of the city. Hope is a crucial player in reducing recidivism

55. Id. at 1,5 .

56. See id.

57. See Taxman, Community Supervision, supra note 20, at 16; see generally Dominic A.S. Pearson et al., Reducing Criminal Recidivism: Evaluation of Citizenship, an Evidence-Based Probation Supervision Process, 7 J. ExPERIMENTAL CRIMINOLOGY 73 (2010). 
and inspiring a crime free lifestyle. ${ }^{58}$ A person who believes in a probationer can trigger desistance; a person who keeps hope alive when the probationer experiences despair is a critical component in the process of changing life patterns ${ }^{59}$ However, hope is a rare commodity in the lives of many probationers. ${ }^{60}$ The social environments in which probationers live tend to stifle hope and in doing so hinder the process of change. ${ }^{61}$ Because of their criminogenic circumstances, surroundings, and characteristics, the prognosis for many repeat offenders is "dire." ${ }^{\prime 2}$ SCRAP's outreach services inject shots of hope into these neighborhoods by bringing in resources, one-on-one assistance, and a real sense of urgency in addressing the needs of the community. SCRAP does the work, follows through, and never gives up.

In the beginning, SCRAP focused its effort on community service projects. The first service project took place during the fall semester of 2016 when students spent the day cleaning and painting at the Partners in Housing buildings on North Pennsylvania Street in downtown Indianapolis. ${ }^{63}$ Partners in Housing rescues and rehabilitates properties that house formerly incarcerated people. The following spring, SCRAP also hosted a canned food and toiletry drive and donated the items to previously incarcerated individuals and their families. ${ }^{64}$ Since then, SCRAP community service has evolved to include outreach workshops to the greater Indianapolis community. SCRAP partners with local reentry organizations, such as Goodwill and the Boys \& Girls Club Reengagement Center, to offer brief service to their clients. Law students, supervised by volunteer attorneys and a faculty member, provide one-on-one assistance to the community on a walk-in basis. The goal is to help people sort through the web of obstacles. These workshops provide assistance with a variety of issues including securing stable housing, gainful employment, driver's licenses, and access to mental health or substance abuse services. Outreach is provided only in "hot spot" zones, ZIP codes designated as high-crime and low-income. These are all in minority neighborhoods. SCRAP knew that engaging in communities absorbing a large portion of the re-entering population provided a better way to leverage scarce resources.

Access to legal services is severely limited, if not nonexistent, for the

58. Fergus McNeill, What Works and What's Just?, 1 Eur. J. Рroв. 21, 27 (2009).

59. Id.

60. Id.

61. Id.

62. Id. "Perhaps because of their experience of adversity, we know from research and practice experience that persistent offenders are very often highly fatalistic; or to use psychological terms, they have 'low self-efficacy' and an 'external locus of control'. They don't feel that they determine the direction of their own lives. Rather, life happens to them." Id.

63. New Student Group Formed to Help Previously Incarcerated Individuals Holds Event and Wins Award, IU RoberT H. MCKinney SCH. LAw (Apr. 14, 2017), https://mckinneylaw.iu.edu/ news/releases/2017/04/new-student-group-formed-to-help-previously-incarcerated-individualsholds-event-and-wins-award.html [https://perma.cc/9CXH-P8ED].

64. Id. 
formerly incarcerated. Because this population is overwhelmingly composed of single men with no children, they do not constitute a special focus category for legal services. ${ }^{65}$ And even if, by the grace of God, legal services had the resources to take a case outside their preference classification, they often find themselves in a conflict of interest due to the organization's representation of an opposing party such as an ex-wife. Left without representation or consultation, and often with no understanding of how to disentangle their circumstances, formerly incarcerated people are left vulnerable. To address this, SCRAP collaborated with various organizations and agencies to facilitate a more streamlined referral process to legal services for formerly incarcerated people. First, SCRAP partnered with Thomas Ridley's 1 Like Me, Inc., to provide reentry outreach culminating in a grant that provides funding to tackle the barriers to reintegration. Next, SCRAP recruited lawyers to supervise reentry outreach efforts and partnered with law firms, such as Faegre Drinker Biddle \& Reath LLP and other firms that are serious about pro bono service. Finally, SCRAP and the Marion County Prosecutor's Office worked together to refer SCRAP's outreach participants living in hot spot zones to the prosecutor's office for driver's license assistance and child support help.

SCRAP's outreach is nothing short of exceptional. Bringing hope to communities in despair is something that cannot be described with words. It only can be witnessed and felt in the air. SCRAP's Hope Hustlers bring the perfect mix of ingredients: hard work, know-how, strong advocacy, and, perhaps most critical, compassion. And, because of SCRAP's character, the community embraces the outreach. In a six-month period, SCRAP provided reentry help to 252 people, with many people returning for assistance with additional issues. Only in its second year, the outreach series is already a well-known service in resource-starved areas.

\section{REENTRY FAIR ${ }^{66}$ \\ "Knowing we needed help, they neglect us \\ Wondering who gon' make them respect us I can see in your eye that you fed up" \\ —Lil' Baby, "The Bigger Picture” (Universal 2020)}

Prior to joining the REACH Team, I surveyed different reentry-related community-based events around the country. I found that traditional reentry initiatives typically take the form of a job fair with a handful of service providers

65. See Legal Servs. Corp., Executive Summary | The Justice Gap: Measuring the Unmet Civil Legal Needs of Low-income Americans, at 3 (June 2017), https://www.lsc.gov/ourimpact/publications/other-publications-and-reports/justice-gap-report [https://perma.cc/VU3RLYKW].

66. Students, Faculty, Alumni Give Back with Annual Re-entry Fair, IU RoBert H. MCKINNEY SCH. LAw (Apr. 23, 2018), https://mckinneylaw.iu.edu/news/releases/2018/04/studentsfaculty-alumni-give-back-with-annual-re-entry-fair.html [https://perma.cc/AR56-AMJU]. 
that distribute informational brochures showcasing their services. Some of the better initiatives offer on-the-spot assistance such as a dental cleaning, HIV testing, a free haircut, or a clothing closet. But for the most part, I discovered reentry initiatives are only informational with little or no on-site assistance. While information is of course invaluable, it falls short of providing the deeper and more meaningful help that this population desperately needs to truly reintegrate. With this, Judge Pryor and I designed a reentry initiative with two primary components: (1) employment and (2) brief service and advice.

With the law school participating in REACH, Judge Pryor and I agreed that we had the capacity to facilitate an initiative that would provide resources and opportunities to formerly incarcerated people in the greater Indianapolis community. In thinking through reentry in the city and the needs of the reentering population, Judge Pryor fervently insisted on a robust employment component. Aware of the correlation between employment and lower recidivism, as well as the public safety benefits, Judge Pryor wanted to target employers that offered a living wage and real advancement opportunities. Students would assist with resume drafting and online applications, thereby providing more comprehensive assistance. My aim was to bring in direct services that address the civil barriers to reentry. Finding resources that would act on a walk-in basis to help individuals disentangle the web of collateral consequences was invaluable. Students, supervised by attorneys, could assist individuals with understanding their child support issues and could also help screen criminal records for expungement eligibility. In addition, students could assist with online public benefits applications that provide health insurance, food stamps, and housing. Together, Judge Pryor and I created a reentry fair that provided holistic, wrap-around services to the formerly incarcerated.

Our first fair was held at the Julia M. Carson Center in Indianapolis on April 8, 2016. McKinney's Black Law Students Association ("BLSA") headed the marketing campaign. BLSA designed the flyer, posted it to various social media outlets (Facebook, Twitter, and Instagram), and distributed it to businesses in low-income neighborhoods around the city, including barbershops, beauty salons, mom and pop eateries, and churches.

BLSA and the United States Attorney's Office were charged with recruiting employers. Notable employers that attended the fair included Mays Chemical, Inc., Office Depot, Barber Construction, and Chipotle. We had over fifteen employers and a number of reentry-focused non-profit organizations in attendance. Law students set up their personal computers connected to one of three mobile Internet power packs provided by the law school to offer direct, oneon-one service in the areas of driver's licenses, child support, and expungement. We arranged stations that provided services in each specific area. Individuals would visit the station(s) that pertained to their specific issue(s). The students searched publicly available information including criminal histories, BMV records, and child support cases and provided limited counsel and assistance under the watchful eyes of licensed attorneys. My valued colleague and friend, Professor Carrie Hagan, took on the enormous task of supervising this component of the event. There was also a probation sign-in area for those on supervision who were required to attend the fair. We served over 200 members of the Indianapolis 
community that year. Using this format as the model, we have made significant improvements over the past three years.

In the following two years, 2017 and 2018, we held the event at Light of the World Christian Church in Indianapolis on the westside. It was a much bigger venue that was located on a bus line and offered parking. In both years, SCRAP, the McKinney Criminal Law Association, and BLSA worked together on marketing, recruitment, and logistics. In both years, the entire REACH Team participated, including the Indiana Federal Community Defenders, the United States Attorney's Office, and the United States Probation Department.

We expanded every aspect of the fair. We increased the number of employers and social service providers twofold and implemented pro bono credit for law students who volunteered. We recruited more students and attorneys. We had seventy-five law student volunteers in 2017 and over 150 in 2018. We also recruited more pro bono attorneys and found that some big firms in Indianapolis such as Faegre Drinker Biddle \& Reath LLP, Ice Miller LLP, and Dentons Bingham Greenebaum were happy to participate and supervise law students in droves, each providing over ten attorneys to supervise law students. Some firms even provided funding to pay for printing costs and food for the volunteers. We added voter registration, a neck-tie giveaway, and a raffle where Assistant United States Attorney Nick Linder emceed the giveaway of fifty-dollar gift cards donated by local big box stores. McKinney professors, such as Michael Pitts, and staff, such as Ketha Troutman and Julie Davis, also volunteered their time to staff the event. Professor Hagan reconfigured the brief service and advice component logistically, established a comprehensive training for each legal service area, and recruited a brilliant legal services attorney, Tracy Pappas, to supervise the child support station. Professor Hagan also integrated her clinic students into the fair operations, empowering them to both provide direct service and take leadership positions at the expungement station. The Indianapolis Metropolitan Police Department ("IMPD") also participated by providing on-site officers at no cost. In both 2017 and 2018, we served over four hundred people in a three-hour period. By 2019, we had the logistics down to a science.

In 2019, we expanded even further. We secured a bigger venue: a mega church named Eastern Star located in the heart of one of the poorest and most dangerous areas in the City of Indianapolis. Like Light of the World, Eastern Star was located on a bus line and offered adequate parking. The 2019 fair was the biggest fair to date. We had over seventy vendors and over two dozen employers. Professor Hagan worked with the Marion County Clerk's Office to facilitate an on-site clerk for the filing of expungement petitions. I worked with the Marion County Prosecutor's Office to secure on-site support in the area of driver's licenses and child support. We had over two hundred volunteers and partnered with other schools at IUPUI, including the Kelley School of Business and the School of Social Work. We added a clothing closet and a public benefits area, and Eastern Star provided food baskets. We hired one of our former REACH participants to DJ the event and Officer Ryan Sharp, our REACH probation officer, headed the probation sign-in area. Law firms continued to contribute and IMPD continued to participate. By this time, Judge Pryor was now in training for her current position as a Federal Magistrate Judge, so she was unable to 
participate but watched from afar. Again, we served over four hundred people.

Due to COVID, we were unable to host a fair in 2020. We were slated to hold the fair at Eastern Star once again with the number of volunteers and vendors already exceeding those of 2019 by the time the event was cancelled. I am confident that the 2020 fair would have been nothing short of a success.

\author{
IV. EXECUTIVE CLEMENCY ${ }^{67}$ \\ "We are all full of weakness and errors; let us mutually pardon \\ each other our follies-it is the first law of nature." \\ -Voltaire
}

While clemency is not directly related to reentry, it is tangentially so and became more connected to reentry in the past five years, particularly during President Barack Obama's final term. The Obama Administration used the presidential power to pardon or commute the criminal sentences of 1,927 individuals. ${ }^{68}$ When President Obama indicated that he was willing to use that power, an amalgam of legal organizations, including the American Bar Association, the American Civil Liberties Union, Families Against Mandatory Minimums, the Federal Public and Community Defenders, and the National Association of Criminal Defense Lawyers, joined together to form a working group called the Clemency Project 2014. ${ }^{69}$ This group recruited hundreds of lawyers across the country to petition President Obama to commute the sentences of thousands of federal inmates. In doing so, they developed a multifaceted executive summary as part of the petition that included a reentry plan upon release. ${ }^{70}$ We here at McKinney reviewed ten cases and accepted nine.

Reentry is a process that begins in prison. Equipping prisoners with the skills necessary to navigate society and encouraging them to think through a reentry strategy prerelease is vital to success. Congress seems to agree. Beginning with the bi-partisan Second Chance Act of 2007, Congress pledged support to state and federal criminal justice agencies working toward the successful reintegration of prisoners back into society. ${ }^{71}$ Federal dollars were allocated to agencies that

67. See IU McKinney Professor, Alumna, See Client's Sentence Commuted, IU Robert H. MCKINNEY SCH. LAW (Oct. 17, 2016), https://mckinneylaw.iu.edu/news/releases/2016/10/iumckinney-professor-alumnae-see-clients-sentence-commuted.html [https://perma.cc/NZ9K-6UTD].

68. Clemency Statistics, U.S. DeP'T JustiCE, https://www.justice.gov/pardon/clemencystatistics\#obama (last visited Sept. 3, 2021) [https://perma.cc/R2T3-RX3X]; see Barack Obama, The President's Role in Advancing Criminal Justice Reform, 130 HARV. L. REV. 811, 837 (2017).

69. Clemency Project 2014: A Historically Unprecedented and Wholly Independent Volunteer Effort by the Nation's Bar, FAMM (Jan. 16, 2015), https://famm.org/clemency-project2014-a-historically-unprecedented-and-wholly-independent-volunteer-effort-by-the-nations-bar/ [https://perma.cc/X66L-WMNE].

70. Executive Summary Template from Clemency Project 2014 (on file with author).

71. 34 U.S.C. § 60501 (2020) [formerly 42 U.S.C. § 17501 (2016)]. 
implemented evidence-based programs. ${ }^{72}$ Most recently, Congress passed the First Step Act of 2018, further emphasizing the importance of reentry programming in prison. ${ }^{73}$ The legislation includes a number of reentry-related provisions such as offering incentives to federal prisoners who participate in recidivism reduction programming ${ }^{74}$ and encouraging federal prisons to partner with community, faith based, and non-profit organizations to provide federal recidivism reduction programming in prison. ${ }^{75}$ With this, government support for prerelease reentry planning has been consistent over the past decade and was thus a natural component of the Clemency Project's executive summary. For me, this piece needed to be well thought through and supported by as much documentary proof as possible.

I formed a team of law students who worked on these cases for experiential credit. We met twice per month to conference on the cases as a group and worked diligently to complete the petition application as well as draft the executive summary and accompanying memorandum. We developed reentry plans for each individual through correspondence with our clients as well as their families. We secured letters of support from family and friends, certificates earned in prison, and personal statements from our clients to demonstrate to the President that our clients were not only worthy of his grace but that the clients had a feasible and practical plan to reintegrate as well as a committed network of support.

McKinney submitted nine petitions for commutation on behalf of federal prisoners. Two of the petitions were denied. Five of the petitions were undetermined by the time President Obama left office in January of 2017. However, two of our petitions were granted. ${ }^{76}$ The first petition granted was on behalf of Mr. Anthony Anderson. Mr. Anderson was convicted of a non-violent drug offense and sentenced to 240 months in prison followed by ten years of supervision. His sentence was commuted by President Obama, and he was released in February of 2017, ten years early. The second petition was granted on behalf of Mr. Lance Foster who, like Mr. Anderson, was convicted of a nonviolent drug offense and sentenced to 240 months in prison. And, for Mr. Foster, as for Mr. Anderson, commutation meant release ten years before his sentence of imprisonment was set to expire.

The reentry plans for both Mr. Anderson and Mr. Foster, as with all of our clients, were comprehensive, well thought through, and feasible. We provided plans for employment, housing, and a prosocial support network. With employment, we worked with clients to develop a strategy that included

72. 34 U.S.C. $§ 10631$ (2020) [formerly 42 U.S.C. § 3797(w) (2016)].

73. 18 U.S.C. $\S 3624$ (2020).

74. 18 U.S.C. $\$ 3624(\mathrm{~g})$. These incentives may include increased phone privileges, additional time for visitation, placement in a facility closer to the prisoner's release residence, increased commissary, and extended email opportunities. 18 U.S.C. $\S 3632(d)$.

75. 34 U.S.C. $\S 60541(\mathrm{~g})$.

76. Letter from Barack Obama, President of the United States, granting application for commutation for Mr. Anthony Anderson and Mr. Lance Foster (on file with author); see IU McKinney Professor, Alumna, See Client's Sentence Commuted, supra note 67. 
employment opportunities with letters backing such prospects, certificates to support the use of real skills with these jobs, and an advancement plan. We dealt with housing in two phases. The first phase provided a housing placement immediately after release from prison, or a halfway house, depending on the individual's sentence. Letters of support from family or friends who guaranteed this immediate housing were attached to the petition application. The second phase offered a long-term plan for independent and stable housing, which included saving for and eventually moving into an apartment or renting a home. Finally, we thought through the criminogenic traits or risks of our clients and addressed each of them. For example, if our client's presentence investigation report reflected a substance abuse issue, we problem-solved a preventative plan that ranged from counseling to twelve-step programming to enrollment in a peer mentoring program. The reentry plan was particularly important because it demonstrated that our clients had really thought about their plans upon release and that these plans were supported by people and organizations outside the prison walls.

The Clemency Project 2014 was a wonderful experience for McKinney students. They took this project seriously and worked tirelessly. The reentry plan allowed the law students to think through the issues that prisoners will face upon release and work to create a plan that addressed these issues. They did a fantastic job. Although we were not successful in all cases, the fact that we did successfully petition in two cases was amazing.

\section{CONCLUSION}

Reentry is much more than preventing recidivism. Reentry is the process of transitioning from prison to society in a productive way. That transition requires participating in society in a legitimate and prosocial manner, severing ties with anti-social peers, and refraining from engaging in criminal behavior no matter how tough the circumstances. In order to successfully reintegrate, formerly incarcerated people need a community that does not stigmatize but instead provides support, assistance, and encouragement, while simultaneously holding people accountable for transgressions. It can be done and is done every day in the City of Indianapolis.

It was in the spring of 2015 that I met with Judge McKinney to discuss the idea and design of a possible mentor program spearheaded by the law school in his reentry court. In those forty-five minutes, Judge McKinney gave me hope that maybe, just maybe, the criminal justice system could do more than punish and imprison the poor and minority groups. Maybe it could actually help. I submit to you, my reader, that today the criminal justice system is helping, and we at McKinney are honored to be a part of it. 